\title{
Meng-Eksistensikan Kembali Budaya Malu Dalam Praktik Penipuan Jual Beli Online Untuk Meningkatkan Perlindungan Konsumen Di Era Revolusi Industri 4.0
}

\author{
Zulfa 'Azzah Fadhlika \\ Fakultas Hukum, Universitas Negeri \\ Semarang \\ Semarang, Indonesia
}

Surel: zulfafadhlika41@gmail.com

\author{
Amarru Muftie Holish \\ Fakultas Hukum, Universitas Negeri \\ Semarang \\ Semarang, Indonesia \\ Surel: muftie199@gmail.com
}

\begin{abstract}
ABSTRAK
Dunia kini telah memasuki era Revolusi Industri 4.0 ditandai dengan penggunaan teknologi disegala bidang. Praktek jual beli sekarang memanfaatkan perkembangan teknologi yang semakin pesat. Metode yang digunakan dalam penelitian ini adalah dengan menggunakan pendekatan kualitatif deskriptif di mana masalah utama akan dijelaskan, dan analisis masalah tentang munculnya pembelian online. Pihak berwenang telah melakukan kejahatan sesuai dengan UU ITE yang sering tidak efektif dan tidak memadai. Budaya malu sebagai kearifan lokal di Indonesia sering membuat orang merasa lebih berhati-hati, karena sanksi sosial yang nyata diperoleh oleh pelaku sering menimbulkan efek jera bagi pelaku dan bukan hukuman pidana. Tapi usia budaya yang berkembang malu mulai menghilang di tengah-tengah zaman.
\end{abstract}

RIWAYAT ARTIKEL

Article History

Diterima : 1 September 2019

Dipublikasi : 25 November 2019

\section{KATA KUNCI}

Keywords

Perlindungan Konsumen, Budaya Malu, Penipuan Jual, Budaya Hukum, Kearifan Lokal

HOW TO CITE (saran perujukan):

Fadhlika, Z. A \& Amarru M. H. (2019). "Meng-eksistensikan Kembali Budaya Malu dalam Praktik Penipuan Jual Beli Online untuk Meningkatkan Perlindungan Konsumen di Era Revolusi Industri 4.0". Jurnal Lex Scientia Law Review. Volume 3 Nomor 2, November, hlm. 155-162

\section{PENDAHULUAN}

Dunia terus mengalami kemajuan disegala bidang. Manusia selalu mencari kenyamanan dan kesejahteraan. Ini upaya manusia membawa perubahan tentang yang sangat cepat di dunia. Salah satu perubahan yang kita benar-benar merasa sekarang adalah globalisasi. Jarak antara satu daerah dengan daerah lain, bahkan satu negara ke negara lain tidak lagi menjadi penghalang dalam era globalisasi ini. 
Dalam era globalisasi hampir semua aktivitas manusia menjadi mudah dan efisien. Meskipun sering menuai pro dan kontra dari pengaruh negatif, tidak dapat dipungkiri bahwa globalisasi sangat membantu untuk kegiatan manusia.

Salah satu bidang yang mengalami perubahan karena globalisasi adalah industri. Industri di dunia telah merevolusi empat kali. Revolusi industri pertama terjadi di Inggris, kemudian menyebar ke daratan Eropa dan Amerika pada pertengahan abad ke-17. Kemudian revolusi industri 2.0 ditandai dengan penggunaan listrik untuk menyederhanakan dan mempercepat proses produksi, distribusi dan perdagangan. The 3.0 revolusi industri yang dikembangkan pada 1970-an, terutama di Amerika Serikat, dengan pengenalan teknologi informasi dan sistem komputerisasi untuk otomatisasi dukungan produksi. Revolusi industri 3.0 menyebar dengan cepat, tidak hanya di Amerika tapi juga telah menyebar ke daratan Eropa ke Asia. Sekarang dunia telah memasuki revolusi industri 4.0. (Ningsih, 2019: 8)

Dunia telah menyambut revolusi industry 4.0 ini dengan inovasi yang memiliki dampak besar pada orang lain dalam industri. Revolusi industri 4.0 juga menyebabkan menjamurnya transaksi online trading. Indonesia berada diperingkat kelima di bawah Korea Selatan dalam kategori pengguna internet. Banyaknya pengguna internet di Indonesia didukung oleh sejumlah besar orang lakukan online jual beli transaksi.

Penjual dan pembeli hari ini tampak lebih mudah dan lebih antusias tentang toko online ini. Pembeli dapat melihat item diposting di media sosial untuk memilih dan melihat harga pertama. Ini lebih efektif dan efisien daripada harus bertemu muka dengan muka. Dengan tersedianya menjual barang secara online memudahkan penjual dan pembeli. Jika pembeli merasa cocok dengan item yang diposting di media sosial, pembeli hanya dapat menghubungi penjual untuk membeli item. Pembayaran dapat dilakukan melalui transfer atau pembayaran digital. Penjual juga tidak perlu untuk mengantarkan barang pribadi. Melalui jasa pengiriman yang saat ini juga tidak kecil jumlahnya, penjual akan tersengat membantu.

Transaksi jual beli merupakan salah satu dari tindakan hukum. Tindakan hukum juga dapat memiliki konsekuensi hukum. Dalam pembelian dan penjualan ada prestasi antara penjual dan pembeli. Pembeli adalah pihak yang memiliki prestasi untuk mentransfer uang kepada penjual. Sebaliknya, penjual memiliki prestasi untuk mengantarkan barang yang telah dipesan oleh pembeli. Maraknya toko online di Indonesia juga telah memberikan peluang bagi tindak pidana. Bahkan ada banyak pelanggaran yang dilakukan oleh salah satu pihak atau kedua belah pihak. Artikel ini akan membahas penipuan yang dilakukan oleh penjual yang menjual barang-barang mereka secara online. penipuan toko online lebih sering dilakukan oleh penjual karena kemudahan membuat akun palsu di media sosial. Hanya dengan membuat akun palsu, menampilkan foto barang yang akan dijual, testimonial palsu, pelanggan kurang jeli akan mudah terkena perangkap 
penipu di balik media sosial ini. Februari 2017 Polda Metro Jaya menerima hampir 100 laporan tentang kasus penipuan pembelian secara online dan penjualan (Ananda, 2017: 3).

(Darmayanti dan Suardita, 2016: 3-4) Penipuan melalui media online telah diatur dalam Undang-Undang Nomor 11 Tahun 2008 tentang Informasi dan Transaksi Elektronik. Namun dalam beberapa kejahatan internet hukum ini juga tidak terlalu ketat dalam hal menyebutkan. (Sjahputra, 2010: 15) Seringkali korban enggan melapor ke pihak berwenang karena nilai transaksi dianggap tidak terlalu besar. Tindakan yang dapat diambil oleh media pemerintah dan sosial yang menghalangi akun palsu. Namun, langkah-langkah represif kurang efektif karena salah satu akun diblokir, maka akun palsu yang hanya muncul kembali.

Salah satu alasan untuk banyak kasus penipuan penjualan online adalah bahwa identitas pelaku tidak diketahui oleh pembeli sehingga pelaku berani untuk melakukan kejahatan ini. Ketika identitas dapat ditutup, maka penjual dilindungi dari jeratan hukum dan rasa malu. Dari latar belakang ini kita tahu bahwa media online secara tidak langsung mengikis salah satu budaya malu bangsa. Budaya malu sebagai kearifan lokal masyarakat Indonesia selama puluhan tahun telah terbukti menjadi jera bagi orang yang ingin melanggar hak asasi manusia. Tapi sekarang budaya malu secara bertahap telah mengungsi akibat globalisasi. Salah satunya adalah budaya malu yang sudah mulai menurun di dunia industri, karena identitas penipu ditutupi oleh media online. Budaya malu perlahan-lahan mulai diabaikan oleh banyak pihak.

\section{Rumusan Masalah}

1. Bagaimana sistem jual beli online?

2. Bagaimana mengeksistensikan kembali budaya malu pada jual beli online?

\section{Metode Penulisan}

Metode yang digunakan dalam artikel ini adalah dengan menggunakan pendekatan deskriptif kualitatif, yaitu pendekatan yang dilakukan dengan cara deskriptif analitis. Kemudian dalam presentasi ini masalah utama akan dijelaskan, analisis masalah akan dilakukan, dan solusi akan diberikan. Data yang digunakan berasal dari berbagai teori yang berasal dari buku, jurnal, hukum dan peraturan, dan literatur lainnya. (Barito, 2009: 17).

\section{PEMBAHASAN}

\section{A. Jual Beli online}

Pembelian dan penjualan proses yang telah terjadi sejak zaman kuno. Meskipun di masa lalu itu masih diklasifikasikan sebagai bentuk sederhana seperti barter, tapi orang-orang telah menyadari bahwa pembelian dan penjualan 
merupakan salah satu kegiatan yang paling penting. Manusia telah menyadari bahwa manusia saling membutuhkan untuk memenuhi kebutuhan mereka. Metode transaksi tertua di dunia terjadi di 6000 SM. Metode barter dipelopori oleh Mesopotamia dan dikembangkan oleh Babel.

Pada tahun 1913, ada kekurangan uang di Amerika Serikat. Pemerintah pada waktu itu tidak mampu mengeluarkan uang lagi karena semua cadangan emas telah digunakan oleh sistem barter ini, karena emas adalah salah satu standar yang digunakan untuk sistem barter. Agar sirkulasi uang untuk menjadi normal kembali, sekelompok orang mendirikan sebuah bank yang disebut "The Federal Reserve Bank of New York" yang kemudian populer disingkat Pakan The. Sejak itu alat pembayaran emas telah berubah menjadi uang kertas. Setelah uang resmi diperkenalkan dan diterima secara luas, uang kertas menjadi alat pembayaran.

Pembayaran dengan uang kertas secara bertahap dirasakan kurang efektif jika pembayaran dilakukan dalam jumlah besar. Akhirnya, otoritas keuangan mengeluarkan alat transaksi disebut Cek dan Bilyet. Keduanya mirip surat pemberitahuan tentang otoritas mengklaim jumlah uang yang dinyatakan dalam nominal dalam Cek / Bilyet Giro. Tetapi dengan perkembangan teknologi, Periksa dan Bilyet mulai digantikan dengan alat pembayaran yang lebih praktis.

Dengan kemajuan teknologi, sistem perdagangan di dunia industri juga telah difasilitasi sehingga penjual dan pembeli lebih memilih jalan praktis. Toko Online adalah sebuah bentuk alternatif bisnis yang dapat digunakan oleh orang-orang bisnis untuk menawarkan produk atau jasa kepada konsumen. Sebagai pengguna layanan internet terus tumbuh, karena menjadi murah dan mudah, bisnis toko online berkembang. Perkembangan bisnis toko online juga didukung oleh peningkatan produktivitas dari industri yang menyediakan berbagai produk yang akan dipasarkan melalui media internet. Hal inilah yang memicu munculnya beli bisnis dan penjualan melalui internet (online shop) karena mudah untuk menjalankan, tidak memerlukan modal yang besar dan tidak harus memerlukan sistem manajemen yang rumit untuk mengelolanya.

Bisnis online berkembang pesat tanpa waktu dan tempat yang terbatas. Membeli dan menjual dengan internet sebagai media penghubung dan website sebagai katalog marketing, lebih praktis dan efisien karena tidak memerlukan pertemuan langsung antara penjual dan pembeli. Membeli produk atau layanan online adalah menjadi berkembang pesat alternatif saat ini. Bahkan bisnis online memiliki banyak keuntungan, yaitu dalam hal pelayanan, efektivitas, keamanan, dan juga popularitas (Laohapensang, 2009).

Banyak toko online dan website di Indonesia sudah dikenal di masyarakat, termasuk toko online dalam tabel adalah toko online yang memiliki aplikasi mereka sendir

Toko Online Terkemuka di Indonesia

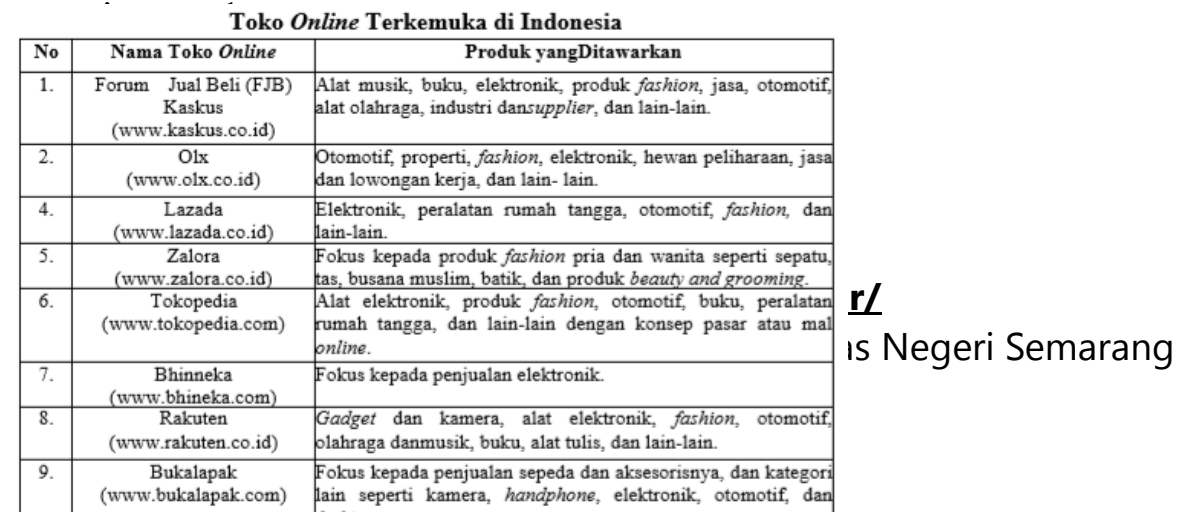

Copyrights $\Subset$ 
Selain toko-toko online di atas, banyak pedagang swasta menjual barang dagangan mereka di media sosial, seperti melalui Facebook, Instagram, garis, dan lain-lain.

\section{B. Penipuan Jual Beli online}

Adanya praktek jual beli secara online menimbulkan peluang untuk penipuan oleh penjual. Bahkan penipuan dilakukan melalui toko online jauh lebih mudah untuk dilakukan karena pelaku lebih bersedia untuk melakukannya. keberanian ini dilatarbelakangi oleh sebuah identitas yang tidak diketahui konsumen terhadap pelaku. Selain itu, jika pelaku telah lancar dilakukan tindakan, ia akan menghindari dengan menghilangkan media sosial cepat. Meskipun dapat dilacak oleh otoritas, tidak jarang bagi konsumen untuk memilih untuk tidak laporan.

Biasanya pelaku akan membajak account yang dianggap menguntungkan, seperti rekening media sosial dari tokoh-tokoh terkenal. Jika sudah mampu dibajak, maka penipuan dapat dilakukan dengan menggunakan akun dari seseorang yang begitu terkenal yang mudah untuk percaya ketika ditawarkan produk, atau lebih buruk lagi, disuruh mentransfer sejumlah uang. Mode penipuan bisnis online yang paling sering ditemukan ketika bertransaksi seperti barang-barang yang tidak ada kasus di Jakarta yang melibatkan salah satu toko online besar di Indonesia, yaitu Lazada diduga penipuan online, di mana pembeli tidak mendapatkan barang sesuai dengan barang yang dibeli. Salah satu kasus yang cukup serius adalah bahwa pembeli berniat untuk membeli iPhone 6 Plus yang benar-benar dikirim mandi sabun bar, dan seseorang berikutnya yang membeli Asus Zenfone 6 "berubah" menjadi dua kotak Kispray pewangi.

Selain penipuan melalui aplikasi online trading, penipuan online trading juga terjadi di media sosial, salah satunya adalah Instagram. Pada aplikasi satu Instagram dapat dengan mudah membuat akun palsu dan membeli pengikut, suka, dan komentar dalam ribuan. Dari instagram itu sendiri telah melakukan tindakan represif seperti pemblokiran account palsu. Bahkan penelitian oleh startup Swedia, A Good Company dan perusahaan analisis data HypeAuditor menunjukkan bahwa Asia telah menjadi bidang penipuan berpengaruh pada Instagram. Indonesia sebagai negara tertinggi keempat yang memiliki paling akun palsu di dunia setelah 
Amerika, Brazil dan India, yang merupakan 25 juta akun palsu. Ini telah memberikan kontribusi terhadap tingginya jumlah penipuan berbasis online di dunia.

\section{Budaya Malu}

(Yuridika, 2018: 142) Unsur teoritis budaya dalam hukum disebut budaya hukum atau budaya hukum adalah salah satu gangguan atas status hukum quo sebagai alat penguasa untuk menciptakan ketertiban. Menurut Soedjito (1986: 127) budaya malu adalah nilai tradisional yang dikembangkan oleh masyarakat untuk mengatur interaksi antara anggota keluarga dan masyarakat secara keseluruhan, sehingga budaya merupakan salah satu unsur yang tidak boleh dilewatkan dalam budaya hukum.

Sebuah budaya malu yang telah diresapi dengan mendarah daging oleh masyarakat dapat dikatakan telah / menjadi lembaga sosial. Dalam budaya malu bentuk lembaga sosial adalah perasaan kehilangan kepercayaan publik yang dipandang sebagai bentuk hukuman yang membuat dicoba orang untuk latihan pengendalian diri "kuat", sanksi sosial semacam ini sebenarnya lebih efektif dari sanksi hukum normatif yang kadang-kadang tidak efektif untuk mencegah seseorang dari melakukan tindakan yang melanggar hukum dan norma-norma sosial lainnya. Oleh karena itu, menurut Soekanto (1983) fungsi lembaga sosial untuk memenuhi kebutuhan masyarakat meliputi:

1. Memberikan pedoman bagi anggota masyarakat bagaimana mereka harus bersikap atau berperilaku dalam menangani masalah di masyarakat.

2. Menjaga integritas masyarakat yang bersangkutan.

3. Memberikan pegangan kepada masyarakat untuk membangun sistem kontrol sosial yang sistem pengawasan masyarakat terhadap perilaku anggotanya.

4. Mencerminkan budaya malu dalam konteks hadir di Indonesia, reality show yang kental dengan nilai-nilai timur dipandang memiliki degradasi berpengalaman dalam menegakkan budaya malu nya.

Saat ini, malu telah mengalami update etika besar, malu tidak lagi perasaan yang harus dilaksanakan dalam konteks kehidupan sosial. Malu, tidak lagi etika atau perasaan, sehingga perasaan seseorang harus halus, yang "malu" akan dapat membentuk kesadaran jiwanya terhadap dirinya sendiri dan masyarakat, tetapi apa yang terjadi adalah justru sebaliknya, kesadaran memudar jiwa bersama dengan hilangnya perasaan malu. Malu, telah dikalahkan oleh kepentingan yang didasarkan pada materi dalam bentuk serangkaian angka kapitalistik (Arief, 2004).

Budaya malu nyata secara teoritis budaya yang tercermin dalam budaya hukum yang harus dimiliki untuk pengembangan era saat ini, karena pengawalan perdagangan melalui dunia maya merupakan kemajuan teknologi yang harus disertai dengan kemajuan dalam budaya hukum dalam masyarakat, penegakan 
hukum ini sejalan dengan dengan efektivitas itu tentu melibatkan budaya malu sebagai unsur yang mendukung penegakan hukum terutama perlindungan dan kesadaran hukum dalam menjaga pengurangan kasus penipuan dalam kasus belanja online.

\section{KESIMPULAN}

Revolusi industri 4.0 telah mendorong masyarakat dunia, serta masyarakat Indonesia untuk terus berinovasi dalam industri perdagangan. Saat ini, kegiatan jual beli yang meningkat, yaitu bisnis jual beli dilakukan secara online karena dianggap lebih praktis dan lebih mudah antara penjual dan pembeli.

Kemudahan dirasakan oleh berbagai pihak tidak dapat dipisahkan dari peluang yang bisa dilakukan oleh salah satu pihak untuk melakukan kejahatan. Kasus jual beli secara online telah menyebabkan banyak penjual untuk melakukan penipuan dalam segala hal sehingga mereka membuat keuntungan langsung. pemerintah memiliki hukum positif untuk menangani kejahatan berbasis secara online ini. Namun hingga saat ini UU masih menuai pro dan kontra sehingga hukum sering kurang efektif dalam kriminalisasi penipu membeli dan menjual secara online. Selain itu, inisiatif masyarakat untuk melaporkan transaksi online masih sangat rendah.

Salah satu latar belakang seseorang menjadi penipu di media sosial adalah karena identitas mereka ditutup, sehingga ia merasa dilindungi dari sanksi sosial yang diberikan oleh masyarakat. Budaya malu yang telah menjadi kearifan lokal di Indonesia secara tidak langsung telah mengikis dengan kemajuan era ini. Meskipun dapat dibuktikan dari banyak kasus kejahatan, para pelaku lebih psikologis tertekan karena malu mereka menderita. Budaya malu harus terus dimiliki untuk pengembangan era sekarang, karena pengawalan perdagangan melalui dunia maya adalah kemajuan teknologi yang harus disertai dengan kemajuan budaya hukum dalam masyarakat. Penegakan hukum yang sejalan dengan efektivitas tentu melibatkan budaya malu sebagai unsur yang mendukung penegakan hukum, terutama perlindungan dan kesadaran hukum dalam menjaga pengurangan kasus penipuan dalam kasus belanja online. Jadi, dengan masyarakat tetap mempertahankan rasa malu ini, tingkat perlindungan konsumen akan meningkat.

\section{DAFTAR PUSTAKA}

D.M.P., Darmayanti, K. Suardita, "Kajian Terhadap Tindak Pidana Penipuan through Jual-Beli Online, " Bali: Universitas Udayana, 2016, hlm.3-4. 
I, Sjahputra, "Konsumen Masih Dirugikan hearts Transaksi Elektroni,", Jakarta, 2010, hlm.15.

J.C., Barito, "Analisis Yuridis Pelaksanaan Privatisasi Badan Usaha Milik Negara (BUMN) di Indonesia Studi KASUS PT. Krakatau Steel (Persero)", Jakarta:. Universitas Indonesia, 2009, hlm 17.

L. D. Ananda, "Dinamika Kepercayaan PADA Pemasaran online di Media Sosial", 1st ed., Vol. 5., Jakarta: Universitas Indonesia, 2017, hlm.3.

M. Ningsih, "Pengaruh Perkembangan Revolusi Industri 4.0 Dalam Dunia Teknologi di Indonesia”, Lampung: Universitas Mitra Indonesia, 2019, hlm.8.

Soekanto, Soerjono. 1983. Sosiologi: Suatu Pengantar. Jakarta: Rajawali.

Sostrodihardjo, Soedjito. 1998. "Kedudukan Hukum Adat hearts Industrialisasi" hearts Hukum Adat Dan Modernisasi Hukum, ed. M. Syamsudin dkk. Jogjakarta FH-UII. 1986. Transformasi Sosial: Menuju Masyarakat Industri”. Jogjakarta: PT. Tiara Wacana. 